\title{
SIGNIFICANCE OF THE LAUSANNE COVENANT
}

\section{About the Congress}

In his long address called "Why Lausanne?" Dr Billy Graham clearly stated the reason and purpose to have the International Congress on World Evangelization by saying that "we are met to pray, talk, plan and to advance the work of evangelism," and he adds: "This is a conference of evangelicals. The participants were asked to come because you are evangelical-concerned with evangelism and missions; and we here tonight stand firmly in the evangelical tradition of Biblical faith." Here we can find two specific reasons for the congress: to discuss for furtherance of world evangelism and to bring evangelicals together for a united front of the world evangelization. For this purpose the invitations were sent to all over the world. According to statistics published officially by the congress six continents sent their representatives to the congress responding to the invitation though it was sent on individual basis: 458 from Africa, 729 from Asia, 1115 from North and Central America, 777 from Europe, 180 from South America and 150 from Oceania. Literally it was a world-wide congress. There was never such a large gathering before on a single purpose.

The congress was represented by 135 denominations with nine major church families. Anglican and Church of England (164), Baptist (658), Bretheren and Missionary Alliance (91), Evangelical (324), Independent (136), Lutheran (229), Methodist (222) and Presbyterian (339) were represented at the congress. As the number of participants shows Baptist and evangelicals were dominant. The planning committee and executive staff headed by Dr D Hoke made so careful and thoughtful planning for the congress that the congress had all the programs smoothly as it was originally scheduled without a single change or delay. Simultaneous translation system of six languages also performed very effectively its function.

The congress has achieved two things for the advancement of the spirit of the congress: to organize a continuation committee with 25 members delegated by the six continents and to make a covenant to be known publicly. Though one of the European speakers urged the congress fervently to organize immediately an organisation as 
counterpart of W.C.C. the congress did not follow his appeal. Instead it appointed the continuation committee to study and to explore for further action and program if it is necessary.

\section{Theological Stand}

In order to confirm and consolidate the spirit of the entire assembly the congress issued a statement of faith called "The Lausanne Covenant" which consists of introduction, fifteen articles and conclusion. Readers of this article, like many who have had some preconception of the congress, may well have already anticipated the theological position which would be expressed, but whether that pre-judgment has proved to be correct only the content of the covenant will tell. For our present purpose let us note briefly what the covenant has to say to a perplexed modern world by examining it article by article.

The introduction of the covenant humbly confesses that the covenanters have failed to complete their mission of world evangelization: "We are deeply moved to penitence by our failure and challenged by the unfinished task of evangelization." The covering statement on what evangelization means is somewhat ambiguous: We believe the gospel is God's good news for the whole world, and we are determined by his grace to obey Christ's commission to proclaim it to all mankind and to make disciples of every nation." This is the main line philosophy of mission advocated today by most churches, and the covenant foliows the traditional position on evangelism. It is not clear, however, whether it understands evangelization in a broader sense to include such newly emphasized areas and methods of mission as industrial mission, lay movement and Missio Dei.

\section{Article 1: The Purpose of God}

This article begins with the traditional confession of faith in the triune God. This God, says the covenant, calls out from the world a people for himself and sends his people back into the world for the fulfilment of God's purpose. But again in a penitential spirit, the covenanters confess their failure to meet this requirement. Too often, they say, we have eitner become conformed to the world or we have withdrawn from it. Most so-called "evangelicals" or "orthodox-conservatives" who represented the dominant 
viewpoint at the congress have believed that the people of God must withdraw from the world in order to remain in faithful relationship with God. But the convenanters clearly confess that this is not right and that withdrawal from the world is a failure. Here we can notic a slight change of understanding about the relationship between the church and the world, which becomes even clearer in the article 5 concerning Christian social responsibility. This represents a clearer focus on and attention to God's purpose in the world.

\section{Article 2: The Authority and Power of the Bible}

It is well known that orthodoxy and evangelicalism are united in their defence of the authority of the Bible. They do not yield to any other position than that of the infallibility of the Bible and its inspiration. So it is no surprise that the covenant affirms "the divine inspiration, truthfulness and authority of both Old and New Testament Scriptures in their entirety as the only written word of God, without error in all that it affirms, and the only infallible rule of faith and practice". It seems to me that the covenant purposefully includes all important conservative theological positions on the Bible and avoids minor disagreements on the issue which may divide evangelicals. Divine inspiration, the truthfulness of both Testaments, the Bible as the only written word of God, and only infallible rule of faith and practice as well as its inerrancy are all affirmed. An important concept, however, is added and should be noticed in the statement that the Bible is "without error in all that it affirms." What does that mean? And what was in the covenanters' minds which they tried to express by that phrase? It may mean that the Scriptures of both Testaments are trustworthy and without error in whatever they affirm positively in all matters described in the Bible. This naturally limits its validity to things specifically and intentionally affirmed in the Bible. It is undeniable fact that there are some error of transmission, corruptions and mistaken documentation. With this fact in mind the covenanters limit the validity of the biblical records only to the things the Bible affirms positively. Or it may mean that since the biblical records are themselves an affirmation of all that the Bible says, the Scriptures are without error in all that it affirms. To the mind of the present writer it would be truer to understand the phrase in the former sense than 
the latter. 'The phrase would seem to be a very delicate and careful way of wording the covenant in order to avoid strong opposition or conflict with biblical literalists. This clause needs more elaborate interpretation and careful discussion, or it could lead to wide disagreements among evangelicals.

In any case, this is an important change in the doctrine of the Bible supported and advocated by conservatives. It has been strongly advocated by many in the past that the Bible is free from all errors in all that it says, including historical references, scientific analysis and its description of the origin of the world. Most evangelicals have accepted Billy Graham's famous catch phrase "the Bible says so" as an unchanging declaration of the authority of the Bible. In this Article, however, that mood is slightly altered by the statement that it is "without error in all that it affirms." The change is from an unconditional approval of the authority to a conditional approval of it.

One other point to be noted in the definition of the authority of Scripture is the phrase "the only infallible rule of faith and practice." To the mind of ordinary Christians, this phrase includes references to the laws of natural science, historiography, economic principles and political philosophy etc. This can lead them to treat the Scriptures as a kind of telephone directory where they expect an answer for any question they may ask, or as an encyclopaedia or a dictionary of law. They insist that the Bible has no errors or corrupted portions whatsoever and consequently they believe that the Bible is inerrant in its entirety. But the covenant carefully confesses that the Bible is "the only infallible rule of faith and practice." What does the phrase "of faith and practice" mean? In general the word faith means religious or spiritual matters, and practice means ethical matters. If that is indeed the meaning of this phrase, we can reword it in the following way: the Bible is the only infallible rule of religious matters and of ethical principles. One who reads the covenant with this understanding should not have any difficulty in signing the covenant. There were many participants, however, who did not sign the covenant mainly because of the ambiguous way the covenant combines the two phrases: "without error in all that it affirms" and "the only infallible rule of faith and practice." 


\section{Article 3: The Uniqueness and Universality of Christ}

The covenant recognizes two types of revelation: general revelation and special revelation. The first is referred to in the phrase, "We recognize that all men have some knowledge of God through his general revelation in nature," which is supported by biblical texts, especially Romans 1:18-32. At the same time the covenant denies the efficacy of general revelation for salvation. One might assume, therefore, that a third alternative would be necessary: a synthesis of general and special revelation, if one alone is not enough for the salvation of men. We may call such a compromise, syncretism. The covenant, however, strongly rejects any kind of syncretism between ideologies, religions and cultural schools. "We also reject as derogatory to Christ and the gospel every kind of syncretism and dialogue which implies that Christ speaks equally through all religions and ideologies." Jesus Christ alone is the ransom for sinners and mediator between God and man. Thus in this third Article the sole power and authority for human salvation is assigned to Christ. The covenant rejects the view that there is any value in other religions for salvation. This automatically shuts the door to dialogue between religions - an emphasis on which has been and still is one of the most popular topics of discussion in ecumenical circles. The covenant exalts Jesus Christ above every other name and longs for the day when every knee shall bow to him and every tongue shall confess him Lord. This is clearly a Christomonism and on this matter the covenant is nearer to Karl Barth's theology than to either orthodoxy or the ecumenical movement.

\section{Article 4: The Nature of Evangelism}

Since the main purpose in gathering the participants together in Lausanne from the four corners of the earth was to reaffirm the urgency of world evangelization and to dedicate themselves to this cause, then this Article on evangelism should be heart of the covenant. Here the congress's fundamental philosophy of evangelism should be found most clearly, persuasively and forcibly. The Article, however, has only a very traditional and superficial definition of the nature of evangelism, simply following old lines of thought which stress personal salvation. Thus the covenant says that evangelism is to persuade 
people to come to Christ personally and so be reconciled to God. But evangelism has been an indispensable aspect of the church's life throughout all ages, and the world with which evangelism deals changes with the process of time. Cultural contexts differ accordingly. We must, then, continually define the nature of evangelism in new ways though the content itself remains the same. On this matter the covenant contains no new approaches to understanding the nature of evangelism and the necessity of it.

\section{Article 5: Christian Social Responsibility}

The reader may well be astonished and amazed at the mode of expression in this Article. We have criticized the fourth article as too customary and superficial in its explanation of the nature of evangelism, but now in the fifth Article the mood completely changes and in strong language the covenant advocates positive involvement of Christians in socio-political movements. One wonders if he is reading a document put out by one of the sociopolitical study groups of the ecumenical movement. Even the vocabulary is the same and the spirit behind the words is very similar. Differences between the two camps of the church, evangelical and ecumenical, seem to disappear. "We affirm that God is both the Creator and the Judge of all men. We therefore should share his concern for justice and reconciliation throughout human society and for the liberation of men from every kind of oppression." There is no doubt that this is a fundamental teaching of the Scriptures. But for many centuries Christian churches were enslaved by a two-world though-pattern or by the Augustinian separation of the two kingdoms civitas Dei et civitas terrena. This concept of separation was more firmly inherited by evangelicals and the orthodoxy. For this reason conservative evangelicals tended to withdraw from the secular world where socio-political involvement creates more acute conflict between church and society. By such withdrawal from a world in which the power of anti-Christ prevails, Christian individuals and churches neglected their duty and responsibility to proclaim the gospel, to protect the righteous and to work with God's reforming power to fulfill God's plan in the world. Recognizing this failure the covenanters boldly and frankly admit their neglect and need of repentance. "Here too we express penitence both for our neglect and 
for having sometimes regarded evangelism and social concern as mutually exclusive. Although reconciliation with man is not reconciliation with God, nor is social action evangelism, nor is political liberation salvation, nevertheless we affirm that evangelism and socio-political involvement are both part of our Christian duty The message of salvation implies also a message of judgement upon every form of alienation, oppression and discrimination, and we should not be afraid to denounce evil and injustice wherever they exist." This kind of activism is strongly urged by the prophets and Jesus Christ, and Christian leaders have advocated it throughout the centuries. In recent years, however, some groups in the churches have neglected this responsibility by separating themselves from the actual world and have taught that withdrawal from the world is the genuine Christian ethic in the world. Evangelical and conservative groups have also maintained the same attitude. Fortunately the covenant recognizes that withdrawal from the world is an error and confesses their failure. The covenant uses the word penitence twice, once in the introduction and a second time in this Article. Many at the congress were startled and puzzled by this part of the confession, disagreeing at first, but later on most of them agreed and signed the covenant with approval. It is the present writer's impression that there is no radical difference between evangelicals and ecumenists as far as the understanding of Christian social responsibility is concerned. We can see here a clear change of attitude among evangelicals on socio-political issues.

\section{Article 6: The Church and Evangelism}

Here again we find a notable change of conception of the church from the traditional one. It has been the conservative view of the church that it is an institution with a certain place, building and structure, and people must go to that place and that building in order to hear the words and the voice of God. This has been described as the "come"type conception of the church. It understands the nature of evangelism as to spread the gospel and to bring back the people who are converted to the church where they will have full salvation. Effective evangelism, according to this traditional view, ends with an increase of church membership. Though evangelicals admit the importance of going out in to the world from the church, yet they have 
often been more concerned and interested in strengthening individual churches. But in this Article a new understanding of the nature of the church is emphasized. If not a radical change, it is at least, without doubt a change of emphasis. Thus the covenant says: "We need to break out of our ecclesiastical ghettos and permeate non-Christian society." Behind this assertion one should not overlook the influence of parachurch organizations such as $\mathrm{C} \mathrm{C} \mathrm{C,} \mathrm{the} \mathrm{Navigators,} \mathrm{and} \mathrm{the} \mathrm{Intervarsity} \mathrm{etc.}$ "The church is the community of God's people rather than an institution." As a matter of fact, there was quite a large number of participants from such para-church organizations mentioned above. One of the key ideas found in this Article - an idea emphasized and stressed by the speakers again and again - was that world evangelization requires the whole church to take the whole gospel to the whole world. This was enthusiastically and rightly approved by the participants.

\section{Article 7: Co-operation in Evangelism}

The covenant encourages the development of regional and functional co-operation for the furtherance of the church's mission, for strategic planning, for mutual encouragement, and for the sharing of resources and experience. One of the speakers furiously decried the ecumenical movement, neo-orthodoxy and liberalism and appealed for the organization of a worldwide association to represent conservative Christianity as a counterpart to the W C C, but his appeal was not heeded quite in the way he wanted. The leaders of the congress were very careful in their criticisms of existing worldwide organizations, and did not commit themselves to starting a new international organization as a counterbalance to the W C C. Yet they did organize a central committee to carry out the purposes of the congress. We must wait and see what kind of purpose and aim this central committee will adopt. In any case the general spirit of the congress was not anti-ecumenical.

\section{Article 8: Churches in Evangelistic Partnership}

The claim that the era of white domination is over seems to be true. In every world-wide church meeting the number of participants from non-white countries or from the third world is being increased. This trend implies that non-white Christians have the responsibility and privi- 
lege of sharing in the enterprises and activities of the church. This was true at Lausanne. The covenant says, "We rejoice that a new missionary era has dawned. The dominant role of western missions is fast disappearing. God is raising up from the younger churches a great new resource for world evangelization." The voice from nonwhite or non-western churches was loud and strong throughout the congress. Participants heard speakers from Asia, the South Pacific, Africa, South America and the Middle East, all of which areas made great contributions to the congress.

\section{Article 9: The Urgency of the Evangelistic Task}

One of the challenging features of the congress was a computer clock which continuously and dramatically reminded the congress how rapidly the world population increases every second, and how slow, by comparison, is the increase of church membership. According to population increase figures, more than two billion seven hundred million people, that is, more than two-thirds of mankind have yet to be evangelized. The covenant therefore states that "we are convinced that this is the time for churches and para-church agencies to pray earnestly for the salvation of the unreached and to launch new efforts to achieve world evangelization." By the end of the congress in the ten days since it started, more than one million eight hundred thousand people had been newly born into the world, whereas who could be sure how many people were newly converted through evangelism during the same period. Every delegate felt the urgency of the world evangelization.

\section{Article 10: Evangelism and Culture}

The covenant re-affirmed the superiority of Christ over culture. Recently there has been a tendency among Christian leaders and theologians to categorize Christianity as one among many religions, making it a relative cultural movement. Evangelicals do not agree. Rather they reaffirm the position that culture must always be treated and judged by Scriptures. Because man has fallen, all his culture is tainted with sin and some of it is demonic. It is obvious that Christianity cannot be identified with any particular culture. Rather churches must seek to transform and enrich culture, all for the glory of God. 


\section{Article 11: Education and Leadership}

To know what the covenant says about this theme it will suffice simply to quote the first few sentences of the article: "We confess that we have sometimes pursued church growth at the expense of church depth, and divorced evangelism from Christian nurture. We also acknowledge that some of our missions have been too slow to equip and encourage national leaders to assume their rightful responsibilities." On this principle some regional and national programs for leadership training are being studied as a follow-up to the congress.

\section{Article 12: Spiritual Conflict}

Here the covenant warns the church that the enemy of Christ does not stay outside the church, but is found also even inside the church. We need both watchfulness and discernment to safeguard the biblical gospel. Whether or not this statement is directed to such Christian leaders as Carl McIntire, it is a fact that he was not welcomed nor allowed to enter the auditorium. On one or two days he brough his group in front of the auditorium carrying a placard reading, "All Christians, come out; there are Communists here." It is a pity that he cannot co-operate with other conservative groups even in the work of world evangelization, and as a result receives no co-operation from them. The congress realised that it has many critics even among conservatives. At the same time the participants felt tnat many churchmen twist the Scriptures and put men in the place of God. Sometimes the church has compromised its message and become unduly preoccupied with statistics or even dishonest in its use of them. This existential situation is exposed in constant spiritual warfare with the principalities and powers of evil. So the covenant says: "we need to equip ourselves with God's armor and to fight this battle with the spiritual weapons of truth and prayer."

\section{Article 13: Freedom and Persecution}

Two thoughs are reflected in this Article: one is the traditional concept of government and the other is the UNIVERSAL Declaration of Human Rights. According to the former every government is under the authority of God and has the God-appointed duty to secure conditions of 
peace, justice and liberty in which the church may obey God, serve the Lord Christ, and preach the gospel without interference. This was Calvin's concept of the nature of government and the relationship between the church and the state. The government often suppressed the churches and interfered with church programs to preach the gospel in many lands. Sometimes separation of church from government was so strongly stressed that the church was not able to speak about peace, justice and liberty in its preaching of the gospel. In other words the church often tends to disregard the socio-political situation and has no contribution to make to the betterment of the world situation. This is more often true of evangelical and conservation churches. The covenanters at Lausanne, however, did not ignore the modern world situation and stood up to join the march on two fronts: to secure socio-political justice and the liberty of the church, and to secure human rights. Evangelicals have been criticised for their intentional co-operation with the State and for siding more of ten with the ruling class than with the oppressed. For the last thirty years the ecumenical camp has fought to secure conditions of peace, socio-political justice, religious freedom and human rights while the evangelicals enjoyed a comfortable increase in church membership through their evangelistic and old-fashioned missionary efforts. But now evangelical leaders feel that it is not enough to take such traditional attitudes and that they have been unduly preoccupied with statistics or even dishonest in their use of them, and they feel that this is the time to shake off the old shell and to work for freedom, for justice, peace, evangelism, and the preservation of human rights. So the covenant says: "God helping us, we too will seek to stand against injustice and to remain faithful to the gospel, whatever the cost." Evangelicals have been always brave and courageous for the gospel but not always for justice and liberty. Now their gospel includes the betterment of socio-political conditions.

\section{Article 14: The Power of the Holy Spirit}

Rightly enough the covenant admits that the Holy Spirit is the God who creates the spirit of world evangelism, continues the enterprise and fulfills the work. As the covenant confesses, world-wide evangelization will become a realistic possibility only when the Spirit renews the church in truth and wisdom, faith, holiness, 
love and power. World evangelization, arising spontaneously from Spirit-filled Christian minds, must be carried out in such a way that the whole earth may hear his voice.

The present writer would like to raise a question in connection with the location of Article 14, though it is of minor importance. The subject of this Article is very important, if not the most important, for world-wide evangelism. Why then could it not be placed after Article three which deals with Christ? By doing so two aspects would be emphasized and strengthened: trinitarian belief in God, and the recognition of the importance of the Holy Spirit for evangelism.

It is interesting to note that in spite of an emphasis on the work of the Holy Spirit, there were no observable activities of charismatic groups throughout the congress. One might have anticipated the emergence of holy rollers, faith healing exercises, or speaking in tongues, but as far as this writer's observation extended there was none of such activities. This indicates a healthy spirit of moderation in the congress and a desire to avoid extreme trends.

\section{Article 15: The Return of Christ}

One of the most widely discussed and defended Christian doctrines among evangelicals and conservatives is the belief in the return of Christ. The covenant clearly confesses its faith in the second coming of Christ by saying, "We believe that Jesus Christ will return personally and visibily, in power and glory, to consummate his salvation and his judgment." We are living, says the covenant, in an interim period between Christ's ascension and return. This interim period is given to be filled with the mission of the people of God, who must not cease their efforts before the End. This is a major motif and thrust for world evangelization. Because of this belief the covenant rejects any idea and hope for a utopia on earth. As Jesus will come physically and personally so the kingdom of God will be perfected and established on earth, and Christ will reign over "the new heavens and the new earth," in which righteousness will dwell and God will rule for ever. In this Article the reader will find two distinct notions about the end of time. The one is as to how Jesus will come. Whether he will return physically and per- 
sonally or only spiritually has been debated among theologians for centuries. The covenant follows and adopts the former position, that is, he will return personally and visibly. The other characteristic of the covenant is the omission of any mentioning of the Millennium. Many of the participants were believers and advocates of chiliasm. But the covenant itself makes no mention of chiliasm and gives no explanation for this omission. The present writer inclines to the view that those who drafted the covenant intentionally avoided mention of this debatable issue knowing that there were many non-chiliasts as well as chiliasts among the participants.

\section{Conclusion}

In the conclusion the covenant invites and urges the participants to enter into a solemn covenant with God and with each other. About two-thirds of the participants entered into this solemn covenant and signed the document.

\section{GENERAL COMMENTS AND REMARKS}

1. The congress was a meeting of Christian individuals from all over the world regardless of denomination, nationality and race. All were invited on an individual basis. No single official delegate from the denominations was present at the congress. This is very different from W C C gatherings which consist of official church delegates. No one from the Roman Catholic Church or the Eastern Orthodoxy Church was invited to the congress.

2 Because of this fact the nature and character of the congress was formulated in such a direction that every one has complete individual liberty and the right to speak out in his own way. In the same way, even the covenant itself has ne binding authority over the participants. Undoubtedly the covenant will be of lasting value in church history as an important document and position paper of the evangelical cause, but it is not expected that established church bodies will adopt it as a authoritative confession or covenant.

3. Most of the covenant is stated in traditional conservative theological terms. Its signers are satisfied and feel comfortable in it. But this means at the same time that it 
breaks few new trails, and contains no new thoughts or insights to meet the challenge of the time and to advance the Christian cause in its struggles to heal the diseases of the contemporary world. If the liberals have failed to save man from his existential problems, leaving him in despair and trembling, so also evangelicals seem to be repeating the same pattern, unable to topple effectively with the problems of todays world. What real benefit is there in a congress which only pronounces a covenant and enables participants to make a few friends from other countries?

4. However, the greatest achievement of the congress, if I may say so, was that it produced a concensus in the minds of the evangelicals and conservatives on sociopolitical problems, an agreement that both evangelism and socio-political involvement are parts of our Christian duty. This implies that evangelism cannot be separated from the socio-political problems and cannot fulfil its purpose in separation from actual society and real history. Until recently evangelicals and conservatives have had a tendency to regard socio-political and economic issues, including human rights and civil rights problems, as having nothing to do with religion. They felt comfortable inside their churches while millions of people throughout the world have been suffering from socio-politico-economic injustice and been threatened to death by the a-moral rulers of the world. But this has changed. Their understanding of Christian social responsibilities has been broadened to bring them much nearer their ecumenist brethren who have fearlessly fought to eliminate all kinds of injustice from human societies. Is it too much to expect that in the near future both evangelical-conservatives and the ecumenists will join hand in hand to engage in the great tast of world evangelization? It is the present writer's firm feeling that there is no serious stumbling block for co-operation between these two camps of the church, namely between the $\mathrm{W} \mathrm{C} \mathrm{C} \mathrm{and}$ the evangelicals. Both camps have a spirit of ecumenicity though each interprets it in different ways. Is there no possibility for both camps to co-operate in one great ecumenical movement in this one world under one flag of the cross?

DR JONG SUNG RHEE PRESBYTERIAN THEOLOGICAL SEMINARY SEOUL, KOREA 